\title{
Compensation for Damage Caused by a Crime in the Socialist Republic of Vietnam and the Russian Federation*
}

\author{
Nguyen Van Tien', Viktor Victorovich Pushkarev², \\ Ekaterina Viktorovna Tokareva ${ }^{3}$, Alexey Vasilyevich Makeev ${ }^{4}$, \\ Olga Rinatovna Shepeleva ${ }^{5}$
}

${ }^{1}$ The People's Police Academy of the Ministry of Public Security of the Socialist Republic of Vietnam (Ha Noi, Vietnam), 2Plekhanov Russian University of Economics (Moscow, Russia), ${ }^{3}$ Leningrad state University named by A. S. Pushkin (St. Petersburg, Russia), ${ }^{4}$ Federal State Budget-Funded Educational Institution of Higher Education "The Russian State University of Justice" (Moscow, Russia)

\subsection{8/jch.v9i2.21738}

\begin{abstract}
In criminal proceedings of Vietnam, in contrast to the Code of Criminal Procedure of the Russian Federation, it is advisable to separate physical, material and moral damage that may be caused by the crime or socially dangerous act prohibited by the criminal law, the rights and legitimate interests of natural or legal persons. The article is devoted to solving the problem of compensation for damage caused by a crime in pre-trial proceedings in criminal cases, based on the study of Russian and Vietnamese criminal procedure legislation, practice, and results of its application. The conclusions are subject to study and implementation in the law.

Keywords: Compensation for harm; Investigation; Rights and legitimate interests of participants in criminal proceedings
\end{abstract}

August, 2021.

* Received: February 12, 2021, revised: April 16, 2021, accepted: June 18, 2021, Published: 31

${ }^{1}$ Nguyen Van Tien, Security Investigation Faculty, The People's Police Academy of the Ministry of Public Security of the Socialist Republic of Vietnam. ORCID: https://orcid.org/0000-0002-6261-4265

2 Viktor Victorovich Pushkarev, Plekhanov Russian University of Economics. ORCID: https://orcid.org/0000-0002-3536-6497

${ }^{3}$ Ekaterina Viktorovna Tokareva, Leningrad state University named by A. S. Pushkin. ORCID: https://orcid.org/0000-0002-3426-7198

${ }^{4}$ Alexey Vasilyevich Makeev, Federal State Budget-Funded Educational Institution of Higher Education "The Russian State University of Justice". ORCID: https://orcid.org/0000-0002-5286-7701

5 Olga Rinatovna Shepeleva, Leningrad state University named by A. S. Pushkin. ORCID: https://orcid.org/0000-0003-1952-2223

Corresponding author: pushkarev.v.v@bk.ru 
Nguyen Van Tien, Viktor Victorovich Pushkarev, Ekaterina Viktorovna Tokareva,

Alexey Vasilyevich Makeev, Olga Rinatovna Shepeleva

\title{
Kompensasi untuk Kerusakan yang Disebabkan oleh Kejahatan di Republik Sosialis Vietnam dan Federasi Rusia
}

\begin{abstract}
Abstrak:
Berbeda dengan Kode Acara Pidana Federasi Rusia, lebih baik dalam proses pidana Vietnam untuk memisahkan kerugian fisik, material, dan moral yang disebabkan oleh kejahatan atau tindakan berbahaya secara sosial yang dilarang oleh hukum pidana dari hak dan kepentingan sah orang atau badan hukum. Berdasarkan kajian undang-undang prosedur pidana Rusia dan Vietnam, praktik, dan hasil penerapannya, artikel ini dikhususkan untuk memecahkan masalah kompensasi atas kerusakan yang disebabkan oleh kejahatan dalam proses pra-persidangan dalam kasus pidana. Kesimpulan sedang dipelajari dan akan dimasukkan ke dalam undang-undang.

Kata Kunci: Kompensasi untuk kerugian; Penyelidikan; Hak dan kepentingan sah peserta dalam proses pidana
\end{abstract}

\section{Возмещение вреда причиненного преступлением в социалистической республике Вьетнам и Российской Федерации}

\begin{abstract}
Аннотация
Статья посвящена разрешению проблемы возмещения вреда, причиненного преступлением, в досудебном производстве по уголовным делам, на основе исследования российского и вьетнамского уголовно-процессуального законодательства, практики и результатов его применения. Выводы подлежат изучению и внедрению в закон

Ключевые Слова: возмещение вреда, расследование, права и законные интересы участников уголовного процесса, следователь, дознаватель
\end{abstract}




\section{A. INTRODUCTION}

In accordance with the Convention for the Protection of Human Rights and Fundamental Freedoms (1950), every individual or legal entity has the right to respect and protect their life, health, morals, property, other rights and legitimate interests, as well as to use the laws and general principles of international law, if they are restricted. The protection of property and non-property rights of the individual is one of the important areas of state activity not only in the Russian Federation (hereinafter referred to as the RF), but also in the Socialist Republic of Vietnam (hereinafter referred to as the SRV). In case of their violation as a result of actions (inaction) that fall under the signs of a crime, there is a need to restore the violated rights, including in the form of compensation (compensation) for damage. The right of a person and a citizen to compensation for damage caused by a crime is constitutional. Thus, in accordance with the Constitution of the SRV of 2013, the right of the victim to compensation for damage caused by a crime is protected by law (art. 14), the right to compensation for harm is granted to any person who is unlawfully subjected to arrest, detention in custody, or criminal prosecution (Part 3 of Article 30) (Constitution of the Socialist Republic of Vietnam, 2013).

\section{B. METHODS}

The methodological basis of the study is the general scientific system method, with which the pre-trial procedure for compensation for damage caused by a crime is formulated as an integral procedural mechanism. The systematic approach made it possible to characterize the institution of compensation for harm caused by a crime as a multidimensional and integral complex of interrelated elements, systematized on the basis of functional and structural links. In order to fully and accurately disclose the subject of the study, special legal methods were used: comparative legal, formal-legal, analysis, synthesis, system, sociological (questionnaires, interviews), etc.

The comparative legal method allowed us to investigate and identify the general provisions of the Criminal Procedure Code of the Russian Federation and the Criminal Procedure Code of the Socialist Republic of Vietnam, regulating the issues of compensation for damage caused by a crime.

The use of the sociological method in the study of criminal cases, interviewing practitioners, allowed us to obtain true results of empirical research, as well as to analyze, systematize and generalize them. 
Nguyen Van Tien, Viktor Victorovich Pushkarev, Ekaterina Viktorovna Tokareva,

Alexey Vasilyevich Makeev, Olga Rinatovna Shepeleva

The formal legal method allowed us to characterize the existing situation associated with the insufficiently effective application of the pre-trial procedure for compensation for damage caused by a crime in the Russian Federation and the Socialist Republic of Vietnam, to analyze and classify the identified problems and to suggest ways for resolving them.

The empirical basis of the research consists of the results of 256 criminal cases study considered in the courts of various regions of the Russian Federation and the Socialist Republic of Vietnam; of 394 respondents survey in the Socialist Republic of Vietnam (among them 162 investigators, 16 interrogators, 12 heads of investigative bodies, 6 heads of inquiry, 46 prosecutors, 32 lawyers, 42 judges, 78 teaching staff of the Academy of People's Security of the Ministry of Public Security of the Socialist Republic of Vietnam).

\section{RESULT AND DISCUSSION}

At present, compensation for damage caused by a crime does not meet the principles of legality and justice and does not correspond to the current level of development of society. Therefore, it requires a theoretical rethinking of the existing scientific views on the compensation of harm caused by a crime, and the justification of new provisions on the determination and compensation of harm caused by a crime in the criminal process of the SRV.

According to the annual statistical reports in the SRV, the damage caused by crimes is compensated in the amount of about 10\%. Thus, in 2017, 1,135,100 crimes were registered in the SRV, which is $2.3 \%$ less than in the same period of 2016. The damage caused by the crimes amounted to $115,011,673,364$ Vietnamese VND, and only $12,002,054,760$ VND was compensated, which is $9.6 \%$.

The situation is similar in the Russian Federation. In the period from January to September 2018, 19.6 thousand people died as a result of criminal attacks $(12.5 \%), 30.1$ thousand people suffered serious harm to their health (25.2\%). Rural areas account for $40.8 \%$ of the dead (8.0 thousand people), cities and urban-type settlements $-67.8 \%$ of people whose health was seriously harmed (20.4 thousand people). The damage caused by crimes (for completed and suspended criminal cases) amounted to 419.6 billion rubles, which is $33.4 \%$ more than the same indicator last year. At the same time, compared to January September 2017, the number of economic crimes detected by Russian law enforcement agencies increased by $3.5 \%$. In total, 93.0 thousand crimes of this category were identified, property damage from which (for completed and suspended criminal cases) amounted to 317.6 billion rubles. 
These statistics reflect the inefficiency in the provision of compensation for damage caused by crime, both in the Russian Federation and in the Socialist Republic of Vietnam.

Currently, in pre-trial criminal proceedings in Vietnam, there are objective and subjective reasons that make it difficult to compensate for the harm caused by the crime.

They include significant gaps in the legislation governing compensation to victims of crimes (Ivanov et al., 2020c, p. 257); the imbalance of the procedural status of the complainant, victim, civil plaintiff, the accused (the defendant), and the civil defendant; the imperfection of the procedural order for compensation of harm caused by the crime (Ivanov et al, 2020a, p. 756); the absence of an effective legal means aimed at compensation for harm to individuals, victims of crime, etc.

The effectiveness of harm compensation to the victim (civil plaintiff) implies the need not only to improve criminal procedural relations in this area (Ivanov et al., 2020b, p. 47) but also to rethink approaches to creating a single mechanism for the legal regulation of this line of action at the level of the state in general and the bodies of the preliminary investigation, in particular.

As the comparative legal analysis shows, the formation process of the criminal procedure legislation of the SRV on issues of compensation for harm to the victim (civil plaintiff) has common features with the legislation of the Russian Federation, but there are also significant differences. Comparison of differences that determine the legal regulation of public relations for compensation for damage caused by the crime, the victim (the claimant) in pre-trial proceedings in criminal cases, will allow us to substantiate a number of proposals aimed at improving the provisions of the criminal procedure law and practice of the Socialist Republic of Vietnam and the Russian Federation.

\section{CONCLUSIONS}

The following concepts should be introduced in the Code of Criminal Procedure of the SRV:

1) the harm caused by a crime is the result of a socially dangerous illegal criminal act that has caused the victim physical, property, moral harm to their rights and legitimate interests;

2) compensation for damage caused by a crime in criminal proceedings is the activity of officials and state bodies of criminal proceedings based on the law, 
Nguyen Van Tien, Viktor Victorovich Pushkarev, Ekaterina Viktorovna Tokareva,

Alexey Vasilyevich Makeev, Olga Rinatovna Shepeleva

entering into criminal procedural relations with other participants and applying appropriate legal means and methods in order to restore the rights and legitimate interests of persons who have suffered as a result of a crime or a socially dangerous act prohibited by criminal law.

Activities for the compensation of damage caused by a crime can be classified into the following three types:

1) criminal procedure - provides compensation for damage at the stages of pre-trial and judicial proceedings;

2) civil law - aimed at resolving a civil claim in the framework of civil proceedings;

3) criminal executive - guarantees a cash payment to compensate for the damage caused by the crime during the serving of the sentence and after the execution of the sentence by the person who caused the criminal damage.

The main features of a civil claim in the criminal proceedings of the Socialist Republic of Vietnam, as an independent legal institution:

1) a civil claim is a complex legal institution that includes criminal procedure and civil law relations;

2) a civil claim is a claim based on the law for compensation for damage caused directly by a crime, a socially dangerous act prohibited by the criminal code or its consequences;

3) the claim for damages is the right of the victim, the private prosecutor, their representatives or legal representatives, the prosecutor representing the interests of the state, as well as other persons affected by the consequences of a crime or socially dangerous acts;

4) a claim for damages is made to the accused or to the person responsible for his actions;

5) a civil claim is aimed at restoring property damage, as well as compensation for physical and moral damage, to a person who has suffered from a crime.

The civil action is a legal claim of individuals or legal entities to receive compensation for damage caused directly by the crime prohibited by the criminal code, socially dangerous acts or the consequences of the offense charged in the criminal case against the accused or the person who bears by law, liable for their actions, and identifying a set of procedural actions and decisions, as well as 
criminal procedure and other legal relations to compensation for property damages and compensation for moral, physical harm.

It is necessary to allocate in the criminal proceedings of Vietnam, in contrast to the Code of Criminal Procedure of RF, the following purposes of property seizure: compensation of damage caused by the crime, in the framework of the civil action; providing possible confiscation as a criminal penalty; enforcement of criminal sanctions in the form of a judicial penalty; protection of property penalties in the form of other procedural costs; the preservation of the property related to the physical evidence in a criminal case; restriction of the right of a legal entity to use, own and dispose of the property.

Seizure of property in criminal proceedings the Socialist Republic of Vietnam is a different measure of procedural coercion used by authorized bodies (officials), conducting criminal proceedings in accordance with legal procedure, towards the accused (the defendant), or persons bearing material liability for their actions, as well as other persons, if there are grounds to believe that they have available the property is associated with the criminal act of the accused (the defendant), for the enforcement of a sentence of the civil action, other property penalties or possible confiscation or other seizure of property obtained as a result of criminal actions or acquired by criminal means.

Proposals for amendments and additions to the Code of Criminal Procedure of the SRV:

- the first part of Article 62 of the Code of Criminal Procedure of the SRV should be worded as follows: "a victim is an individual or a legal entity who has suffered physical, property or moral damage to their rights and legitimate interests through a crime or an act prohibited by criminal law. The decision on recognition as a victim is taken immediately from the moment of initiation of a criminal case and is formalized by the decision of the investigator";

- paragraph "g" of part two of article 62 of the Criminal Procedure Code of Vietnam to read as follows: "the victim is entitled to be informed of the compensation for harm caused by a crime or is prohibited by the criminal code of socially dangerous acts, including the voluntary compensation of harm, criminal procedure restitution and application of a civil lawsuit to seek their application in the recovery of property damages, compensation, physical and moral damages, and costs incurred in connection with their participation in the preliminary investigation and in court, including the costs of the representative";

- the first part of Article 128 of the Criminal Procedure Code of the SRV should be worded as follows: "the seizure of property is applied to the accused, 
the defendants, other persons, if there are grounds to believe that they have property obtained by criminal means by the accused or the defendant, as well as persons who are legally liable for their actions;

- the second part of Article 128 of the criminal procedure code of Vietnam is to be read as follows: "the property shall be seized by order of the officials referred to in paragraph "a" of article 113 of this Code, a prosecutor or a decision of the officials referred to in paragraphs " $\mathrm{b}$ " and " $\mathrm{C}$ " of article 113 of this Code, as well as judges presiding in court. The officials specified in paragraphs " $\mathrm{b}$ " and "c" of Article 113 of this Code, as well as the judges presiding at court sessions, have the right to entrust the production of this investigative action to the investigative body";

- to make amendments to Article 128 of the Criminal Procedure Code of Vietnam part 21, which will be read as follows: "in cases of urgency, a lien on the property may be seized without a warrant, but with subsequent notification of the prosecutor with a copy of the order and protocol within twenty-four hours. The circumstances that do not tolerate delay are subject to justification in the notification sent to the prosecutor";

- to supplement Article 128 of the Code of Criminal Procedure of the SRV with part five of the following content: "when seizing property, a specialist or an evaluation organization may be involved. The property to be seized is valued at the current market prices at the time of valuation, taking into account depreciation. Money, bonds, cheques, shares, and other securities are accounted for at par";

- to supplement Article 128 of the Code of Criminal Procedure of the SRV with part six of the following content: "when seizing property to ensure the execution of a sentence in a civil claim, the protocol includes property whose value is sufficient to compensate for damage, including for payment of procedural costs and declared moral damage";

- to complete part three of article 147 of the Criminal Procedure Code of Vietnam provisions on the possibility of obtaining explanations from the applicants, citizens and other persons with information about the crime, and the possibility of production of examination of documents and objects, in which there is evidence of crime as well as on the amount and size caused by the crime harm. 


\section{REFERENCES}

Convention for the Protection of Human Rights and Fundamental Freedoms. Concluded in Rome on November 4, 1950 (as amended on 13.05.2004). Sobranie Zakonodatel'stva Rossiiskoi Federatsii [SZ RF] [Collection of Legislation of the RF] 08.01.2001, No. 2, Item 163.

Constitution of the Socialist Republic of Vietnam. (2013). Official Gazette No. 1003-1004 dated December 29, 2013.

Ivanov, D.A., Esina, A.S., Fadeev, P.V., Chasovnikova, O.G. \& Zorina, E.A. (2020a). Crime victim compensation. Revista Gênero e Direito. Vol. 9, No. 4, 753-759.

Ivanov, D.A., Fadeev, P.V., Alimamedov, E.N. \& Dung, V.K. (2020b). Provision of the rights and legitimate interests of legal entities that have been victims of crimes. Revista Turismo Estudos \& Práticas. No. S5, 47.

Ivanov, D.A., Tokareva, E.V., Shepeleva, O.R., Chasovnikova, O.G. \& Statsyuk, D.N. (2020c). Compensation for damage caused by a crime in pre-trial proceedings in criminal cases: issues of theory and practice. Revista Inclusiones. Vol. 7, No. S4-7, 255-263. 
Nguyen Van Tien, Viktor Victorovich Pushkarev, Ekaterina Viktorovna Tokareva,

Alexey Vasilyevich Makeev, Olga Rinatovna Shepeleva 